\title{
Real life results of coil treatment for bronchoscopic lung volume reduction in emphysema
}

\author{
Demet TURAN ${ }^{1}$ (ID) \\ Deniz DOĞAN ${ }^{2}$ (ID) \\ Mustafa ÇÖRTÜK ${ }^{1}$ (ID) \\ Efsun Gonca UĞUR \\ CHOUSEIN $^{1}$ (ID) \\ Elif TANRIVERDi ${ }^{1}($ ID) \\ Binnaz Zeynep \\ YILDIRIM ${ }^{1}$ \\ Barış DEMIRKOL ${ }^{1}$ (ID) \\ Halit ÇINARKA ${ }^{1}($ ID $)$ \\ Mehmet Akif ÖZGÜL ${ }^{1}$ (ID) \\ Erdoğan ÇETINKAYA ${ }^{\mathbf{1}}$ (ID)
}

Cite this article as: Turan $D$, Doğan $D$, Çörtük $M$, Uğur Chousein EG, Tanriverdi E, YIldirim BZ, et al. Real life results of coil treatment for bronchoscopic lung volume reduction in emphysema. Tuberk Toraks 2020;68(1):1724.

\section{Yazışma Adresi (Address for Correspondence)}

\section{Dr. Demet TURAN}

İstanbul Yedikule Gögüs Hastalıkları ve Göğüs Cerrahisi Eğitim ve Araştırma Hastanesi, Göğüs Hastalıkları Kliniği,

ISTANBUL - TÜRKIYE

e-mail: drdemetturan@gmail.com

\footnotetext{
CCopyright 2020 by Tuberculosis and Thorax.
}

Available on-line at www.tuberktoraks.org.com
${ }^{1}$ Clinic of Chest Diseases, Yedikule Chest Diseases and Chest Surgery Training and Research Hospital, Istanbul, Turkey

${ }^{1}$ istanbul Yedikule Göğüs Hastalıkları ve Göğüs Cerrahisi Ĕ̆itim ve Araştırma Hastanesi, Göğüs Hastalıkları Kliniği, İstanbul, Türkiye

${ }^{2}$ Department of Chest Diseases, Faculty of Gulhane Medicine, Health Sciences University, Ankara, Turkey

2 Sağlık Bilimleri Üniversitesi Gülhane Tıp Fakültesi, Göğüs Hastalıkları Anabilim Dalı, Ankara, Türkiye

\begin{abstract}
Real life results of coil treatment for bronchoscopic lung volume reduction in emphysema

Introduction: The lung volume reduction coil treatment is a minimally invasive bronchoscopic treatment option for emphysema patients who suffer from severe hyperinflation. Previous studies have reported successful outcomes in selected cases using coil for bronchoscopic lung volume reduction (BLVR). Our aim is to determine the changes in respiratory function tests, perception of dyspnea and exercise capacities after 12 months in patients treated with endobronchial coil.
\end{abstract}

Materials and Methods: The data of patients with severe emphysema and treated with coils between 2014-2017 were evaluated retrospectively. Dynamic and static lung volume capacities at baseline and 12 months, modified Medical Research Council (mMRC) questionnaire and six-minute walk test (6-MWT) results were recorded.

Results: BLVR was performed in thirty patients (one female, twenty-nine males). Five patients were treated bilaterally and twentyfive unilaterally. One patient died after 7 days and 4 patients died during follow-up. Five patients were lost to follow-up. A total of twenty patients with available data were included in the study. A statistically significant difference was found in $\mathrm{mMRC}$ results in pre-treatment and 12-month evaluations. There was no significant difference in FEV, TLC and RV values at the end of 12 months. There was an increase of 18.9 meters $( \pm 83.5 \mathrm{~m})$ between the baseline and 12 months in 6-MWT. $45 \%$ of the patients improved their walking distance over 26 meters which is known as minimal clinically important difference (MCID).

Conclusion: Although no significant changes were observed in pulmonary function tests and lung volumes, the increase in exercise capacity and decreased perception of dyspnea indicate the efficacy of endobronchial coil.

Key words: Bronchoscopy; lung volume reduction; coil; emphysema 
ÖZ

\section{Amfizemli hastaların bronkoskopik volüm azaltıcı coil tedavisinin gerçek yaşam sonuçları}

Giriş: Akciğer volüm azaltıcı coil tedavisi, şiddetli hiperinflasyonu olan amfizem hastaları için minimal invaziv bir bronkoskopik tedavi seçeneğidir. Yapılan çalışmalarda, seçilmiş olgularda başarılı sonuçlar bildirilmiştir. Amaçmız endobronşiyal coil tedavisi uygulanan hastalarda, solunum fonksiyon testleri, dispne algısı ve egzersiz kapasitelerinin 12. ay sonundaki değişikliklerini değerlendirmektir.

Materyal ve Metod: Şiddetli amfizemi olan ve 2014-2017 yılları arasında endobronşiyal coil tedavisi uygulanan hastaların verileri retrospektif olarak değerlendirildi. Başlangıç değerleri ve 12 ay sonunda dinamik ve statik akciğer hacmi kapasiteleri, "modified Medical Research Council (mMRC)" skorları ve altı dakikalık yürüme testi (6-MWT) sonuçları kaydedildi.

Bulgular: Bronkoskopik akciğer volüm azaltıcı coil tedavisi, 30 (1 kadın, 29 erkek) hastaya uygulandı. Beş hasta bilateral, 25 hasta unilateral tedavi aldı. Bir hasta işlemden yedi gün sonra, dört hasta takip sırasında eksitus oldu. Beş hasta takiplerine gelmedi. Çalışmaya 12. ay verileri bulunan 20 hasta dahil edildi. mMRC sonuçlarında tedavi öncesi ve 12 aylık değerlendirmelerde istatistiksel olarak anlamlı bir fark bulundu. On iki ay sonunda FEV arasında $18.9 \mathrm{~m}( \pm 83.5 \mathrm{~m})$ artış oldu. Hastaların \%45'i yürüme mesafesini, minimal klinik anlamlı sonuç (MCID) olarak bilinen 26 m'nin üzerinde artırdı.

Sonuç: Solunum fonksiyon testlerinde ve akciğer hacimlerinde anlamlı bir değişiklik gözlenmemesine rağmen, egzersiz kapasitesindeki artış ve dispne algısındaki azalma endobronşiyal coil tedavisinin etkinliğini göstermektedir.

Anahtar kelimeler: Bronkoskopi; akciğer volüm azaltma; coil; amfizem

\section{INTRODUCTION}

Chronic obstructive pulmonary disease (COPD) is a common, preventable and treatable disease characterized by persistent respiratory symptoms and airflow restriction caused by abnormalities in airways and/or alveoli because of noxious particles and gases (1). Emphysema, which is defined as the abnormal and permanent dilatation of airways distal to the terminal bronchioles, accounts for more than $30 \%$ of COPD patients. This permanent dilatation in airways causes hyperinflation, which is the main reason of dyspnea and reduced exercise capacity in emphysema $(2,3)$. Treatments reducing this hyperinflation might relieve dyspnea and increase quality of life and exercise performance $(4,5)$.

For patients with severe emphysema, main treatment options are; smoking cessation, bronchodilators, anti-inflammatory drugs, vaccinations, pulmonary rehabilitation, long term oxygen treatment, non-invasive ventilatory support and surgical interventions like lung volume reduction surgery and lung transplantation. However, despite all these treatment options, the majority of patients still remain highly symptomatic or do not qualify for surgical techniques and lung transplantation.

In recent years, minimal invasive bronchoscopic treatment options for severe emphysema have been developed, such as endobronchial valves, lung volume reduction coils and experimental techniques such as bronchoscopic thermal vapor ablation and biological lung volume reduction (aeriseal lung sealant), all targeting hyperinflation (2,6-9). Also very new airway-directed treatments such as targeted lung denervation and metered liquid nitrogen cryospray are being researched $(10,11)$.

Surgical lung volume reduction treatments have been replaced by bronchoscopic lung volume reduction treatments in selected cases due to early postoperative complications and high mortality rates (12-14). For patients with interlobar collateral ventilation, coils might be a potential treatment option (15). Recently, successful results have been reported with coil treatment which is defined as one of bronchoscopic lung volume reduction (BLVR) methods used in severe emphysema (16).

In our study, we aimed to determine whether there were any changes in respiratory function test parameters, perception of dyspnea and exercise capacity in emphysema patients in real life after coil placement in a period of 12 months.

\section{MATERIALS and METHODS}

\section{Study Design}

The data of the patients were evaluated retrospectively. The study protocol was approved by the Ethics Committee of Karabuk University (Ethics number: 03.01.2018/1-29). The data of the patients who were diagnosed with severe COPD-emphysema and treated with coil between 2014-2017 were examined. The results of the modified Medical Research Council (mMRC) questionnaire for perception of dyspnea, 
6-minute walk test (6-MWT) for exercise capacities and dynamic and static lung volume capacities of the patients were recorded before and 12 months after the treatment.

\section{Patients' Selection}

Patients with severe COPD-emphysema were selected for endobronchial coil treatment. The thoracic computed tomography (CT) imaging was used to assess the heterogeneous and homogenous emphysema and the patients who were eligible for treatment after pulmonary rehabilitation were included in the study, if (16):

1. There was heterogeneous and homogenous emphysema,

2. The expected Forced Expiratory Volume in one second $\left(\mathrm{FEV}_{1}\right)$ values were between $15-45 \%$,

3. The expected residual volume (RV) values were $>$ $200 \%$, total lung capacity (TLC) $>100 \%$,

4. The expected diffusing capacity of the lungs for carbon monoxide (DLCO) values were $>20 \%$,

5. The patient could walk between 140-450 meters in 6-MWT,

6. $\mathrm{SPAB}$ in echocardiogram was $<50 \mathrm{mmHg}$,

7. The patient was receiving optimum bronchodilator treatment,

8. The patient had quit smoking at least 8 weeks ago,

9. The patient had been treated with pulmonary rehabilitation at least six weeks before the procedure,

10. Anticoagulant or antiplatelet treatment could be stopped before the procedure,

11. Radiologically absence of bronchiectasis and sequelaes.

Thoracic high resolution computed tomography (HRCT) and lung perfusion scintigraphy data were used to select the lung lobe for coil placement. The lobes with severe emphysema area in HRCT and decreased perfusion on quantitative perfusion scintigraphy were determined as the treatment area (17).

\section{Treatment Procedure}

Coil treatment was performed under general intravenous (IV) anesthesia by the guidance of fluoroscope with flexible bronchoscope (inner diameter $2.8 \mathrm{~mm}$ ) via rigid bronchoscope or endotracheal tube.

The bronchial system of the target lung lobe of the intubated patient was first examined. The coils made of nitinol in appropriate lengths (RePneu LVR coil, PneumRx Inc, Mountain View, CA USA; 100 mm, $125 \mathrm{~mm}$ and $150 \mathrm{~mm}$ ) (Figure 1) and straightened forms; via delivery catheter were transferred into the sub-segmental areas of the target lobe with a $2-3 \mathrm{~cm}$ margin to the pleura under fluoroscopic guidance (Figure 2). The direction of the coils faced the hilum of the lung and they were placed like a bunch of roses (Figure 3). After the procedure, a chest X-ray control was done immediately if the patient has symptoms like chest pain or dyspnea, if not; after 2 hours. All patients were followed up for 3 to 5 days in the hospital and were given methylprednisolone $(0.5 \mathrm{mg} / \mathrm{kg})$ and empirical antibiotics for 5 days.

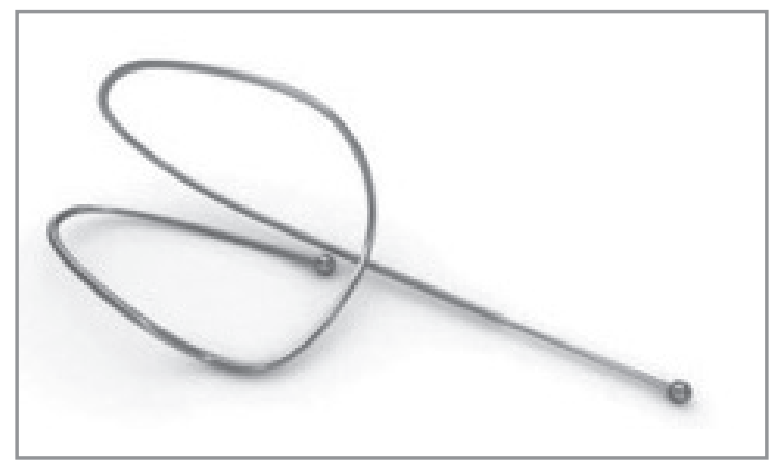

Figure 1. Endobronchial coil.

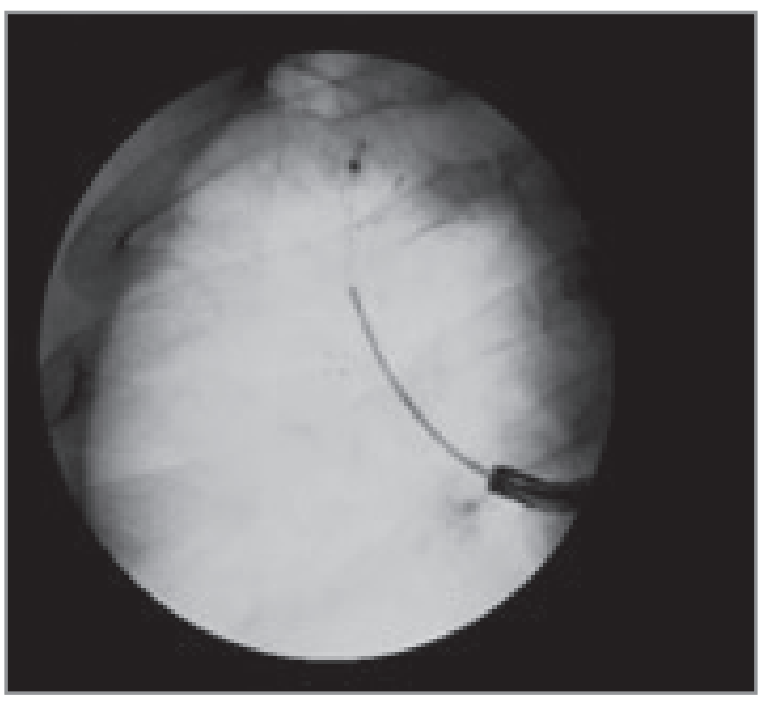

Figure 2. Fluoroscopic image during coil placement, showing the distal end of the coil with the distal end of the catheter position. 


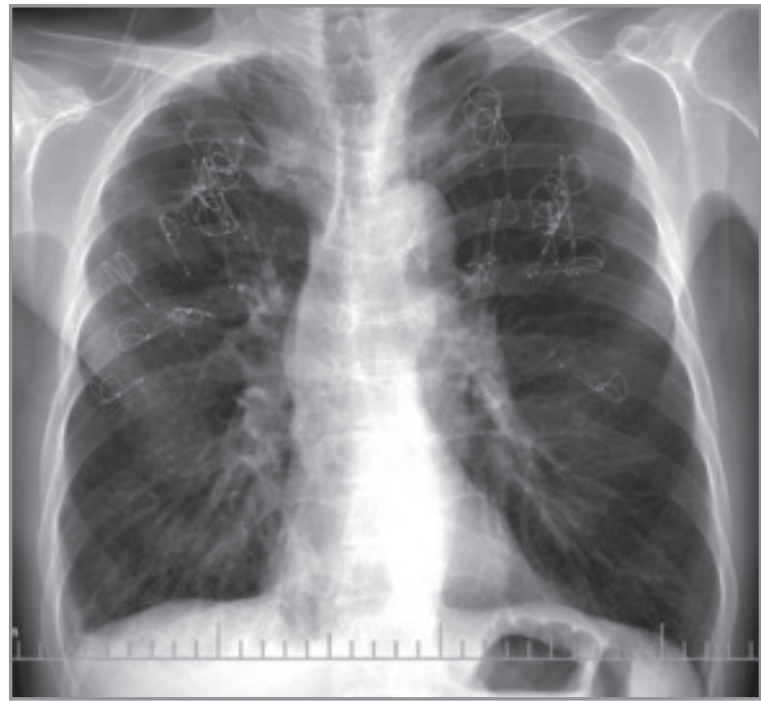

Figure 3. Chest X-ray of a patient after bilateral coil placement in upper lobes.

\section{Statistical Analyses}

All variables are presented as minimum, maximum, mean and \pm SD. The Kolmogorov-Smirnov test was used to control whether the variables were distributed normally.

In the analysis of the control parameters of the baseline and 12 months' baseline, "paired t-test" was used for the normally distributed variables and "Wilcoxon signed rank test" was used for the variables that were not distributed normally. A $p$ value of $<0.05$ was taken statistically significant.

\section{RESULTS}

A total of 30 patients ( 1 female, 29 males) underwent bronchoscopic lung volume reduction coil treatment between 2014-2017. A total of 35 procedures were performed in 30 patients, bilaterally in 5 patients. The total number of coils used in procedures were 313. The coil placement regions were as follows; right upper lobe $60 \%$, right lower lobe $22.8 \%$, left upper lobe $8.5 \%$ and left lower lobe $8.5 \%$ (Table 1 ). The demographic datas, basal pulmonary function test parameters, lung volumes, mMRC questionnaires and 6-MWT results are summarized in Table 2. One patient died of massive hemoptysis on the $7^{\text {th }}$ day after the coil placement which was accepted as an early mortality due to the procedure. Four patients

\begin{tabular}{|lc|}
\hline Table 1. Procedural results & \\
\hline Parameter & No \\
\hline Total coil procedures & 35 \\
Unilateral coil patients & 25 \\
Bilateral coil patients & 5 \\
Total coil placed & 313 \\
100 mm & 190 \\
125 mm & 123 \\
Coils placed per subject, median & 9 \\
Prefered lobes & \\
Right upper lobe & 21 \\
Right lower lobe & 8 \\
Left upper lobe & 3 \\
Left lower lobe & 3 \\
\hline
\end{tabular}

Table 2. Basal values of the patients treated with coil

\begin{tabular}{|c|c|c|c|c|}
\hline Variables & Minimum & Maximum & Mean & $\pm \mathrm{SD}$ \\
\hline Age (years) & 54 & 76 & 63.6 & 5.6 \\
\hline Smoking (packs/year) & 10 & 150 & 54.5 & 39.8 \\
\hline $\mathrm{TLC}(\mathrm{L})$ & 5.99 & 17.14 & 8.32 & 2.14 \\
\hline $\mathrm{TLC}(\%)$ & 101 & 264 & 135.4 & 31.1 \\
\hline $\mathrm{RV}(\mathrm{L})$ & 3.49 & 15.05 & 5.84 & 2.11 \\
\hline RV (\%) & 226.1 & 588.3 & 269.2 & 69.1 \\
\hline $\mathrm{RV} / \mathrm{TLC}$ & 59 & 88 & 69.6 & 6.7 \\
\hline $\mathrm{FEV}_{1}(\mathrm{~L})$ & 0.41 & 1.17 & 0.79 & 0.17 \\
\hline $\mathrm{FEV}_{1}(\%)$ & 13.0 & 41.0 & 28.1 & 7.0 \\
\hline 6-MWT (m) & 143 & 435 & 295.2 & 88.4 \\
\hline $\mathrm{mMRC}$ & 3 & 4 & 3.7 & 0.47 \\
\hline
\end{tabular}


Turan D, Doğan D, Çörtük M, Uğur Chousein EG, Tanrıverdi E, Yıldırım BZ, et al.

Table 3. 12 month follow-up basal values of the patients after coil treatment

\begin{tabular}{|c|c|c|c|c|}
\hline Variables & Minimum & Maximum & Mean & $\pm \mathrm{SD}$ \\
\hline Age (years) & 54 & 74 & 62.5 & 5.5 \\
\hline Smoking (packs/year) & 10 & 150 & 50.2 & 34.4 \\
\hline $\mathrm{TLC}(\mathrm{L})$ & 5.99 & 17.14 & 8.32 & 2.14 \\
\hline TLC (\%) & 107 & 154 & 136 & 14.3 \\
\hline $\mathrm{RV}(\mathrm{L})$ & 4.21 & 8.16 & 5.91 & 1.17 \\
\hline RV (\%) & 226 & 335 & 267.25 & 37.3 \\
\hline RV/TLC & 59 & 77 & 69.9 & 5.56 \\
\hline $\mathrm{FEV}_{1}(\mathrm{~L})$ & 0.47 & 1.17 & 0.84 & 0.17 \\
\hline $\mathrm{FEV}_{1}(\%)$ & 18 & 39.9 & 29.3 & 6.4 \\
\hline 6-MWT (m) & 142 & 435 & 266.8 & 96.3 \\
\hline $\mathrm{mMRC}$ & 3 & 4 & 3.7 & 0.4 \\
\hline
\end{tabular}

died during the 12-month follow up, two of four because of acute myocardial infarction and the remaining due to respiratory failure. Five patients were excluded as they were lost to follow-up or due to lack of sufficient data. The life status of these patients was confirmed by telephone and checked by the Ministry of Health Death Notification System database. Twenty patients who were still alive at 12 months' baseline with complete data were included in the study. Pulmonary function tests, lung volumes, mMRC questionnaires and 6-MWT results are summarized in Tables 2 and 3, before and after treatment.

A statistically significant difference was found in the pre-treatment and 12 months' mMRC questionnaires ( $3.7 \pm 0.4$ vs. $1.9 \pm 0.6$, mean -1.8 points, $p<0.001)$. The baseline and 12 months' $\mathrm{FEV}_{1}$ values were $0.84 \pm$ $0.17 \mathrm{~L}$ and $0.86 \pm 0.25 \mathrm{~L}$, respectively, with a mean change of $0.02 \mathrm{~L}(1.3 \%)$ which was not statistically significant $(p=0.681)$. The TLC values were $136 \pm$ $14.3 \%$ and $129.8 \pm 25.9 \%$ at the baseline and 12 months, respectively with a mean decrease of $0.14 \mathrm{~L}$ $(6.25 \%)$ which was not statistically significant $(p=$ $0.249)$. The RV values were $267.25 \pm 37.3 \%$ and $243.35 \pm 87.1 \%$ at the baseline and 12 months' respectively with a mean decrease of $0.14 \mathrm{~L}(23.9 \%)$ which was not statistically significant. The 6-MWT results were (min: $142 \mathrm{~m}$, max: $435 \mathrm{~m}$ ) at the baseline and (min: $145 \mathrm{~m}$, max: $450 \mathrm{~m}$ ) at the 12 months which indicated a mean improvement of $18.9 \mathrm{~m}( \pm 83.5 \mathrm{~m})$. More than $40 \%$ of the patients improved their walking distance by 26 meters, which is the minimal clinically important difference. All pulmonary function tests and
mMRC scores of the study population at the baseline and 12 months are given in Table 4.

\section{DISCUSSION}

COPD is a chronic inflammatory disease with airflow limitation causing dyspnea. It is an end result of longterm exposure to noxious particles or gases and smoking (1). Treatment options for the patients with severe COPD include smoking cessation, beta-2 agonists, anticholinergic drugs, oral/inhaled steroids, oxygen therapy and pulmonary rehabilitation. However, since the efficacy of these treatment options is limited and only a number of selected patients can benefit from these modalities, it is recommended to use bronchoscopic interventional treatment options with level B evidence, especially in patients with COPD and severe emphysema who are still symptomatic despite standard medical treatments (1). The aim of using coils is to reduce the volume of emphysematous lung parenchyma by shrinking and letting the airflow go through the part of lung which has better perfusion and ventilation. Coil treatment is an effective treatment option in selected patients, regardless of collateral ventilation.

We presented 12-months' reallife long-term results of severe emphysema patients who underwent bronchoscopic lung volume reduction coil treatment. Our study showed only statistically significant improvement in MMRC score. On the other hand; at the end of the 12-month follow-up period, we found that $\mathrm{FEV}_{1}$ values and 6-MWT results were improved, the TLC and RV values were decreased. 
Results of coil in lung volume reduction

Table 4. Control parameters and variability rates at $12^{\text {th }}$ month after coil treatment $(n=20)$

\begin{tabular}{|c|c|c|c|c|c|c|c|}
\hline Variable & & $\mathbf{n}$ & Minimum & Maximum & Mean & $\pm \mathrm{SD}$ & p \\
\hline \multirow[t]{3}{*}{ TLC (L) } & Before & 20 & 6.09 & 10.79 & 8.41 & 1.25 & 0.676 \\
\hline & After & 20 & 5.05 & 12.91 & 8.27 & 1.99 & \\
\hline & Difference & 20 & -3.91 & +2.12 & -0.14 & 1.54 & \\
\hline \multirow[t]{3}{*}{ TLC (\%) } & Before & 20 & 107 & 154 & 136 & 14.3 & 0.249 \\
\hline & After & 20 & 77 & 179 & 129.8 & 25.9 & \\
\hline & Difference & 20 & -70 & +33 & -6.25 & 23.5 & \\
\hline \multirow[t]{3}{*}{$\mathrm{RV}(\mathrm{L})$} & Before & 20 & 4.21 & 8.16 & 5.91 & 1.17 & 0.681 \\
\hline & After & 20 & 2.35 & 11.16 & 5.77 & 2.14 & \\
\hline & Difference & 20 & -3.25 & +3.0 & -0.14 & 1.58 & \\
\hline \multirow[t]{3}{*}{ RV (\%) } & Before & 20 & 226 & 335 & 267.25 & 37.3 & 0.121 \\
\hline & After & 20 & 97 & 450 & 243.35 & 87.1 & \\
\hline & Difference & 20 & -136 & +116 & -23.9 & 65.8 & \\
\hline \multirow[t]{3}{*}{ RV/TLC } & Before & 20 & 59 & 77 & 69.9 & 5.56 & 0.485 \\
\hline & After & 20 & 58 & 86 & 68.9 & 8.27 & \\
\hline & Difference & 20 & -12 & +10 & -1 & 6.51 & \\
\hline \multirow[t]{3}{*}{$\mathrm{FEV}_{1}(\mathrm{~L})$} & Before & 20 & 0.47 & 1.17 & 0.84 & 0.17 & 0.683 \\
\hline & After & 20 & 0.51 & 1.46 & 0.86 & 0.25 & \\
\hline & Difference & 20 & +0.43 & +0.51 & +0.02 & 0.24 & \\
\hline \multirow[t]{3}{*}{$\mathrm{FEV}_{1}(\%)$} & Before & 20 & 18 & 39.9 & 29.3 & 6.4 & 0.521 \\
\hline & After & 20 & 16 & 58 & 30.6 & 10.4 & \\
\hline & Difference & 20 & -17 & +18.1 & +1.3 & 8.4 & \\
\hline \multirow[t]{3}{*}{ 6-MWT (m) } & Before & 20 & 142 & 435 & 266.8 & 96.3 & 0.400 \\
\hline & After & 20 & 145 & 450 & 285.7 & 94.6 & \\
\hline & Difference & 20 & -95 & -198 & +18.9 & 83.5 & \\
\hline \multirow[t]{3}{*}{$\mathrm{mMRC}$} & Before & 20 & 3 & 4 & 3.7 & 0.4 & $<0.001$ \\
\hline & After & 20 & 1 & 3 & 1.9 & 0.6 & \\
\hline & Difference & 20 & -3 & 0 & -1.8 & 0.7 & \\
\hline
\end{tabular}

In our study, the mean $\mathrm{FEV}_{1}$ was increased $0.02 \mathrm{~L}$ $(1.3 \%)$ at the end of the 12-month period. The change in $\mathrm{FEV}_{1}$ over time is very important as it guides the clinician in monitoring the degree and severity of the disease. FEV 1 decreases with age, especially after 25 and smoking increases the rate of this decline. Fletcher and Peto have measured $\mathrm{FEV}_{1}$ values in every six months in an eight-year period and they have shown that $\mathrm{FEV}_{1}$ decreases dramatically after 50 years of age, especially in case of smoking. The average annual loss of $\mathrm{FEV}_{1}$ in non-smokers was $42 \pm 6 \mathrm{~mL}$ and $66 \pm 4 \mathrm{~mL}$ in people smoking more than $15 \mathrm{cig}$ arettes a day in their study (18). In other studies on this subject, the mean annual loss of FEV 1 in COPD stage
III and IV patients ranged between 23-59 mL (19-21). Although the improvement in $\mathrm{FEV}_{1}$ was not statistically significant, there was no expected annual loss of $F E V_{1}$ in this patient group. FEV $_{1}$ was used to evaluate the degree of obstruction in the airways.

The main cause of dyspnea in patients with COPD and emphysema is high residual volume. The aim of coil therapy is to reduce the high residual volume and perception of dyspnea. Our study also showed that, at the end of 12 months, RV and TLC values decreased by 0.14 and $0.14 \mathrm{~L}$, respectively.

At the end of 12 months, there was a $0.14 \mathrm{~L}(-6.25 \%)$ decrease in TLC and a $0.14 \mathrm{~L}(-23.9 \%)$ decrease in 
RV. In a 1/1 randomized multicentre REVOLENS study conducted in France, the results of 50 patients who underwent coil treatment and followed up for twelve months has shown an increase in $\mathrm{FEV}_{1}$ by $0.05 \mathrm{~L}(8 \%)$, decrease in RV by $0.47 \mathrm{~L}(-9 \%)$ and TLC by $0.29 \mathrm{~L}(-3 \%)$ in coil treatment group (22).

On the other hand, in the RENEW study, recruiting 315 patients with severe emphysema in a three-year period, endobronchial coil treatment and standard methods have been compared. The patients have been randomized as $1 / 1$ and the mean change rate of $\mathrm{FEV}_{1}$ has been found to be $3.8 \%$ increased at the end of the first year in a total of 158 patients who underwent bilateral coil treatment (5). In a meta-analysis by Slebos et al., the results of four different clinical studies covering a total of 2536 coils in 140 patients have been compiled. The lung volume capacities and pulmonary function test parameters have been evaluated at 12 months in 96 patients. It has been found that the $\mathrm{FEV}_{1}$ values were significantly improved by $0.08 \mathrm{~L}( \pm$ 0.21 ) at 12 months after the treatment. TLC has changed by $-0.22 \mathrm{~L}( \pm 0.55)$ and the RV has changed by $-0.43 \mathrm{~L}( \pm 0.72)$ for the same period of time (6). All these studies show that endobronchial coil treatment prevents annual loss of $\mathrm{FEV}_{1}$ and decreases RV in selected patients, as in our patient group.

Another common clinical problem in patients with COPD is the relatively low exercise capacity. In our study group, the 6-minute walking distance (6-MWD) was $266.8 \pm 96.3$ meters and there was an increase of $18.9 \pm 83.5$ meters 12 months after the treatment. On the other hand, $45 \%$ of the patients improved their walking distance over 26 meters which is known as minimal clinically important difference (MCID). Similar to our results, the RENEW study reported an average of $10.3 \mathrm{~m}$ increase in 6-MWD at the end of the first year and $40 \%$ of the patients improved at least $26 \mathrm{~m}$ (5). In another study, the change was $-2 \mathrm{~m}(-29$ to 25$)$ at the end of the $12^{\text {th }}$ months (10). In Slebos' study, the walking distance was $+38.1 \mathrm{~m} \mathrm{( \pm 71.9)}$ at 12 months (6). All of these results show us that endobronchial coil treatment has positive effects on walking distance in COPD patients with severe emphysema. Our results are concurrent with the literature in regards to 6-MWT.

Dyspnea is the most common reason affecting the quality of life in patients with COPD. Since dyspnea is a subjective feeling, the only way of evaluation is the patients' statements and/or internationally vali- dated questionnaires. In this study, the mMRC questionnaire was used to evaluate dyspnea. An average score of $-1.8(3.7 \pm 0.4$ vs. $1.9 \pm 0.6)$ was recorded at the end of 12 months for the perception of dyspnea. The REVOLENS study has reported a 0.5 point decrease at the end of the first year (22). In a previously published meta-analysis, the data of 95 patients who were followed-up for twelve months have been evaluated and the variability of $\mathrm{mMRC}$ results have been found similar, as $0.53( \pm 0.86)(6)$.

The limitations of our study are the lack of a control group and the retrospective design. But as a retrospective study, instead of a prospective design, it gives us an important knowledge about real life outcomes. Another limitation of our study is, due to the reimbursement practices of the social security institution in our country most of the procedures are done unilaterally.

In conclusion, although this study did not statistically prove significant changes in pulmonary function test values and lung volumes, increased exercise capacity and decreased perception of dyspnea indicate the efficacy of endobronchial coil treatment. On the other hand, the lack of expected annual average $\mathrm{FEV}_{1}$ loss in this patient group can be considered as a success of the treatment.

\section{CONFLICT of INTEREST}

There is no conflict of interest related to this study.

\section{AUTHORSHIP CONTRIBUTIONS}

Concept/Design: DT, EÇ

Analysis/Interpretation: ET, BK

Data Acquisition: EGUC, BZY, DT

Writting: DD, DT

Critical Revision: $\mathrm{HÇ,} \mathrm{MÇ}$

Final Approval: MAÖ, EÇ

\section{REFERENCES}

1. Global Strategy for the Diagnosis, Management, and Prevention of Chronic Obstructive Pulmonary Disease Revised 2018. Global Initiative for Chronic Obstructive Lung Disease (GOLD 2018).

2. Cooper CB. The connection between chronic obstructive pulmonary disease symptoms and hyperinflation and its impact on exercise and function. Am J Med 2006;119:2131.

3. O'Donnell DE, Laveneziana P. Dyspnea and activity limitation in COPD: mechanical factors. COPD 2007;4:225-36. 
4. Klooster K, ten Hacken NH, Hartman JE, Kerstiens HA, van Rikxoort EM, Slebos DJ. Endobronchial valves for emphysema without interlobar collateral ventilation. N Engl J Med 2015;373:2325-35.

5. Sciurba FC, Criner GJ, Strange C, Shah PL, Michaud G, Connolly TA, et al. Effect of endobronchial coils vs. usual care on exercise tolerance in patients with severe emphysema: the RENEW randomized clinical trial. JAMA 2016;315:2178-89.

6. Slebos DJ, Hartman JE, Klooster K, Blaas S, Deslee G, Gesierich W, et al. Bronchoscopic coil treatment for patients with severe emphysema: a meta-analysis. Respiration 2015;90:136-45.

7. Herth FJ, Valipour A, Shah PL, Eberhardt R, Grah C, Egan J, et al. Segmental volume reduction using thermal vapour ablation in patients with severe emphysema: 6-month results of the multicentre, parallel-group, open-label, randomised controlled STEP-UP trial. Lancet Respir Med 2016;4:185-93

8. Come CE, Kramer MR, Dransfield MT, Abu-Hijleh M, Berkowits $D$, Bezzi $M$, et al. A randomised trial of lung sealant versus medical therapy for advanced emphysema. Eur Respir J 2015;46:651-62.

9. Mineshita M, Slebos DJ. Bronchoscopic interventions for chronic obstructive pulmonary disease. Respirology 2014;19:1126-37.

10. Slebos DJ, Klooster K, Koegelenberg CF, Theron J, Styen D, Valipour $A$, et al.Targeted lung denervation for moderate to severe COPD: a pilot study. Thorax 2015;70:411-9.

11. Slebos DJ, Breen D, Coad J, Klooster K, Hartman J, Browning $R$, et al. Safety and histological effect of liquid nitrogen metered spray cryotherapy in the lung. Am J Respir Crit Care Med 2017;196:1351-2.

12. The National Emphysema Treatment Trial Research Group. Rationale and design of the national emphysema treatment trial a prospective randomized trial of lung volume reduction surgery. Chest 1999;116:1750-61.

13. Flandes J, Francisco JS, Cordovilla R, Cases E, Alfayate J. Bronchoscopic lung volume reduction. Clin Chest Med 2018;39(1):169-80.
14. Kontogianni K, Gerovasili V, Gompelmann D, Schuhmann $M$, Heussel CP, Herth FJ, et al. Effectiveness of endobronchial coil treatment for lung volume reduction in patients with severe heterogeneous emphysema and bilateral incomplete fissures: a six-month follow-up. Respiration 2014;88:52-60.

15. Welling JBA, Slebos DJ. Lung volume reduction with endobronchial coils for patients with emphysema. I Thorac Dis 2018;10(Suppl 23):S2797-S2805.

16. Fishman A, Martinez $F$, Naunheim K, Piantadosi S, Wise $R$, Ries $A$, et al. A randomized trial comparing lung-volume reduction surgery with medical therapy for severe emphysema. N Engl J Med 2003;348:2059-73.

17. Yıldız F. Ağır amfizem için hacim azaltıcı sarmal tedavisi öncesi kantitatif perfüzyon sintigrafisi değerlendirmesinin işlemin etkinliğini belirlemedeki rolü. Tuberk Toraks 2017;65(2):106-11.

18. Fletcher $C$, Peto $R$. The natural history of chronic airflow obstruction. Br Med / 1977;1(6077):1645-8

19. Jenkins $C R$, Jones PW, Calverly PM, Celli B, Anderson JA, Ferguson GT, et al. Efficacy of salmeterol/fluticasone propionate by GOLD stage of chronic obstructive pulmonary disease: analysis from the randomised, placebo-controlled TORCH study. Respir Res 2009;10:59.

20. Decramer M, Celli B, Kesten S, Lystig T, Mehra S, Tashkin DP. Effect of tiotropium on outcomes in patients with moderate chronic obstructive pulmonary disease (UPLIFT): a prespecified subgroup analysis of a randomised controlled trial. Lancet 2009;374(9696):1171-8.

21. Burge PS, Calverley PMA, Jones PW, Spencer S, Anderson JA, Maslen TK. Randomised, ouble blind, placebo controlled study of fluticasone propionate in patients with moderateto severe chronic obstructive pulmonary disease: the ISOLDE trial. BMJ 2000;320(7245):1297-303.

22. Deslee G, Mal H, Dutau H, Bourdin A, Vergnon JM, Pison $C$, et al. Lung volume reduction coil treatment vs usual care in patients with severe emphysema: the REVOLENS randomized clinical trial. JAMA 2016:315:175-84. 